resectron

\title{
UII and UT in grouper: cloning and effects on the transcription of hormones related to growth control
}

\author{
Caiyun Sun*, Da Duan**, Bo Li, Chaobin Qin, Jirong Jia, Bin Wang, \\ Haiyan Dong and Wensheng Li
}

\begin{abstract}
State Key Laboratory of Biocontrol, Institute of Aquatic Economic Animals and Guangdong Provincial Key Laboratory for Aquatic Economic Animals, School of Life Sciences, Sun Yat-Sen University, No. 135, XinGang West Road, Guangzhou 510275, People's Republic of China

*(C Sun and D Duan contributed equally to this work)

${ }^{\dagger}$ (D Duan is now at Department of Neurosurgery, Second Affiliated Hospital of Hunan Normal University, Changsha, Hunan, China)
\end{abstract}

\author{
Correspondence \\ should be addressed \\ to W Li \\ Email \\ Isslws@mail.sysu.edu.cn
}

\begin{abstract}
Urotensin II (UII) is a cyclic peptide that was originally extracted from the caudal neurosecretory system (CNSS) of fish. Ull is well known to exhibit cardiovascular, ventilatory, and motor effects in vertebrates. Studies have reported that Ull exerts mitogenic effects and can act as an autocrine/paracrine growth factor in mammals. However, similar information in fish is limited. In this study, the full-length cDNAs of UII and its receptor (UT) were cloned and characterized in the orange-spotted grouper. UII and UT were expressed ubiquitously in various tissues in grouper, and particularly high levels were observed in the CNSS, CNS, and ovary. A functional study showed that UT was coupled with intracellular $\mathrm{Ca}^{2+}$ mobilization in HEK293 cells. Studies carried out using i.p. injections of Ull in grouper showed the following: i) in the hypothalamus, UII can significantly stimulate the mRNA expression of ghrh and simultaneously inhibit the mRNA expression of somatostatin 1 (ss1) and ss2 $3 \mathrm{~h}$ after injection; ii) in the pituitary, Ull also significantly induced the mRNA expression of $g h 6$ and $12 \mathrm{~h}$ after injection; and iii) in the liver, the mRNA expression levels of ghr1/ghr2 and igf1/igf 2 were markedly increased 12 and $3 \mathrm{~h}$ after the i.p. injection of Ull respectively. These results collectively indicate that the UII/UT system may play a role in the promotion of the growth of the orange-spotted grouper.
\end{abstract}
Key Words
- orange-spotted grouper
- urotensin II
- growth
- mRNA expression

- UT
Journal of Endocrinology (2014) 220, 35-48

\section{Introduction}

Urotensin II (UII) is a cyclic neuropeptide that was first isolated from the urophysis of the teleost fish goby Gillichthys mirabilis (Pearson et al. 1980) and subsequently identified in many vertebrates, such as frogs (Conlon et al. 1992), humans (Coulouarn et al. 1998), mice, and rats (Coulouarn et al. 1999). The mature form of UII has a cyclic structure formed by a disulfide bond at the C terminus, in which the '-Cys-Phe-Trp-Lys-Tyr-Cys-' sequence is fully conserved across vertebrate species, whereas the amino acid sequence at the $\mathrm{N}$ terminus is rather variable (Onan et al. 2004, Conlon 2008, Vaudry et al. 2010). Comparative genomic studies have shown that the UII and somatostatin (SS) genes derive from a common ancestral gene (Tostivint et al. 2006, 2008). Both these genes share the common -Phe-Trp-Lys- sequence, which is functionally important. Soon after the

Published by Bioscientifica Ltd. 
identification of UII in humans (Coulouarn et al. 1998), GPR14, which is an orphan receptor, was first identified as the receptor of UII (Ames et al. 1999). The UII receptor, now renamed UT, is a member of the family of G-proteincoupled receptors (GPCRs; Onan et al. 2004). UT shares high sequence identity with the SS receptors (SSTRs). Both UT and one of the SSTRs, SSTR3, are located on the same chromosome (Tostivint et al. 2006, 2008). In mammals, both UII and UT are widely expressed in the CNS and various peripheral tissues (Onan et al. 2004, Malagon et al. 2008). UII has been cloned from many fish species, such as flounder (Lu et al. 2006), killifish (Evans etal. 2011), and eels (Nobata et al. 2011). Although the caudal neurosecretory system (CNSS) is the major site of UII expression, as in mammals, UII is also widely expressed in the CNS, such as in the optic nerve, different parts of the brain, hypothalamus, pituitary, and spinal cord, and in peripheral tissues, including gill, head kidney, kidney, bladder, stomach, intestine, rectum, heart, spleen, liver, and ovary (Lu et al. 2006, Evans et al. 2011). The mRNA expression of UT has been identified in the CNSS, CNS, and different peripheral tissues of fish (Lu et al. 2006, Evans et al. 2011).

The widespread distributions of UII and UT indicate their multiple physiological actions in vertebrates. In mammals, UII is well known for its smooth-musclestimulating activity and is considered the most potent mammalian vasoconstrictor (Ames et al. 1999). Numerous studies have demonstrated that the UII/UT system is involved in the control of cardiovascular activity (Watson \& May 2004, Vaudry et al. 2010), locomotor activity, orexigenic and dipsogenic response (Do-Rego et al. 2005), sleep (de Lecea \& Bourgin 2008), and endocrine hormone secretion (Gartlon et al. 2001). Moreover, some recent studies in mammals have shown that i) UII exerts mitogenic effects on some tumor cells, such as SW-13 cells (Takahashi et al. 2003) and pheochromocytoma cells (Zeng et al. 2006); ii) hUII is an autocrine/paracrine growth factor in porcine renal epithelial cells (Matsushita et al. 2003) and involved in the pathogenesis of vascular remodeling (Zhang et al. 2008); and iii) UII can stimulate the proliferation of human lung adenocarcinoma A549 cells, induce an increase in tumor volume and weight ( $\mathrm{Wu}$ et al. 2010), and promote the proliferation of rat bone marrow-derived endothelial progenitor cells (Xu et al. 2012). These results collectively indicate that the UII/UT system acts as an autocrine/paracrine growth-stimulatory factor in the regulation of physiological actions in mammals. Although UII was first isolated from fish more than 30 years ago (Pearson et al. 1980), the study of the physiological functions of the UII/UT system in fish is far behind that in mammals. In addition to the studies on the roles of UII in smooth-muscle contraction (Bern et al. 1985), cardiovascular activity (Le Mevel et al. 2008, Nobata et al. 2011), and locomotor activity (Le Mevel et al. 2008), most of the studies on fish have focused on its osmoregulatory functions (Vaudry et al. 2010), such as its inhibitory effects on prolactin release in tilapia (Seale et al. 2013) and $\mathrm{NaCl}$ transport across the opercular epithelium in killifish (Evans et al. 2011). However, to the best of our knowledge, a study similar to that conducted on the role of UII as an autocrine/paracrine growth factor in mammals has not been carried out yet in fish.

The orange-spotted grouper (Epinephelus coioides) is a commercially significant fish with a high economic value. It is widely cultured in the tropical and subtropical regions of Southeast Asia. The extremely low larval survival rate and the slow growth of the fingerlings have been the major obstacles in grouper aquaculture (Wu et al. 2012). Understanding growth regulation in grouper is important for improving their growth efficiency in aquaculture. It is well known that the growth hormone (GH)/insulin-like growth factor (IGF) system plays a major role in the coordination of the growth of vertebrates, including fish (Reindl \& Sheridan 2012). The aim of this study was to investigate the hypothesis that the UII/UT system might act as an autocrine/paracrine growth factor in the regulation of the gene transcription of major hormones related to the growth of grouper. To achieve this purpose, the full-length cDNAs of UII and UT were first isolated from grouper. The mature peptides of UII and urantide, which is a specific antagonist of UT, were synthesized for a functional study, and after the construction of a UT expression vector, the functional properties of UT and the synthesized UII were characterized by an expression study of UT in human embryonic kidney 293 (HEK293) cells and intracellular $\mathrm{Ca}^{2+}$ measurements using a confocal technique. Finally, the effects of i.p. injections of UII on the mRNA expression of GH-releasing hormone ( $g h r h), s s 1, s s 2, g h$, GH receptor 1 (ghr1), ghr2, igf1, and igf2 were examined. This study indicates that the UII/UT system may play a role in the regulation of the growth of the orange-spotted grouper.

\section{Materials and methods}

\section{Animals}

The orange-spotted grouper used for the in vitro study were obtained from the Huangsha market for aquatic products in Guangzhou, China. Two-year-old orange-spotted grouper with body weights (BWs) of 500-750 g were used

Published by Bioscientifica Ltd 
for molecular cloning and tissue distribution studies. Eight-month-old grouper with BWs of 50-55 g, obtained from the Guangdong Daya Bay Fishery Development Center in Huizhou, China, were used for i.p. injection studies. For in vivo experiments, fish were cultured in a 1501 tank at a density of 12 fish per tank. These fish were allowed to acclimatize for 2 weeks in a recirculating seawater system at $25-28{ }^{\circ} \mathrm{C}$ under natural photoperiod conditions and fed commercial feeds until satiety two times daily during the experimental period. At the experimental end points, all fish were killed by anesthesia in $0.05 \%$ MS222 (Sigma) followed by decapitation. The target tissues were removed and snap-frozen in liquid nitrogen immediately, followed by storage at $-80^{\circ} \mathrm{C}$ until RNA extraction. All the animal experiments were carried out in accordance with the guidelines and approval from the Sun Yat-Sen University Animal Care and Use Committee.

\section{Total RNA extraction and first-strand CDNA preparation}

Total RNA was isolated from different tissues by TRIzol/ chloroform extraction using TRIzol Reagent (Invitrogen) according to the manufacturer's instructions. The final RNA concentration was determined by optical density (OD) measurements at $260 \mathrm{~nm}$ using a NanoDrop 1000 spectrophotometer (Thermo Fisher Scientific, Waltham, MA, USA). The integrity of RNA samples was verified by measuring the ratio of ODs at 260 and $280 \mathrm{~nm}$. Only the RNA samples that had a ratio $>1.8$ were used for subsequent cDNA synthesis. After the removal of residual contaminating DNA with DNase I (NEB, Ipswich, MA, USA), $2 \mu \mathrm{g}$ of total RNA isolated from samples of each tissue were reverse-transcribed into first-strand cDNA with oligo-dT/gene-specific primers (cloning or $3^{\prime} / 5^{\prime}$ RACE) or random primers (real-time PCR) using the Superscript III Kit (Invitrogen).

\section{Molecular cloning of CDNAs of UII and UT in orange-spotted grouper}

The molecular cloning of UII and UT was carried out by nested PCRs coupled to $5^{\prime} / 3^{\prime}$ RACE. Primers used for the isolation of the full-length cDNAs of the two genes are given in Supplementary Table 1, see section on supplementary data given at the end of this article. Degenerate primers used to obtain the first fragment of UII or UT were designed based on the conserved regions of UII reported in fugu (GenBank: CAI63878.1), flounder (GenBank: CAD56908.1), and medaka (GenBank: XP_004070888.1) or UT reported in flounder (GenBank: CAI30311.1) and zebrafish (GenBank: XP_001335317.1). Total RNA was extracted from the CNSS and spinal cord tissue samples and reverse-transcribed into the first-strand cDNA. For the cloning of the first fragment of UII, PCR was carried out using the first-strand cDNA prepared from the CNSS as a template to pull out a partial sequence of UII, while for that of UT, the first-strand cDNA prepared from the spinal cord was used as a template. Based on the sequences obtained, specific primers were designed for $3^{\prime} / 5^{\prime}$ RACE using the GeneRacer Kit (Invitrogen) to isolate the full-length cDNAs of UII and UT. The amino acid sequences of UII and UT were deduced using the DNAtools, version 6 Software (DNAtools Inc, Fort Collins, CO, USA). The alignment of the amino acid sequences was determined using the DNAssist, version 2.2 Software (www.dnassist. soft32.com). The domains of the transmembrane helices were predicted using the TMHMM program, version 2.0 (www.cbs.dtu.dk/services/TMHMM-2.0/).

\section{Tissue distribution analysis of UII and UT expression in orange-spotted grouper}

For the tissue distribution analysis, total RNA was extracted from the tissue samples of the CNSS, spinal cord, pituitary, forebrain, midbrain, hindbrain, hypothalamus, heart, kidney, spleen, rectum, gill, and ovary of three individual fish. After RNA extraction and reverse transcription, the first-strand cDNA samples that were obtained were used as templates for real-time PCR using the UII-QT-F and UII-QT-R primers for UII and the UT-QT-F and UT-QT-R primers for UT respectively. Real-time PCRs were carried out on the LightCycler 480 Sequence Detection System (Roche) using a SYBR Select Master Mix Kit (Invitrogen). The PCRs were conducted with the following thermal cycling parameters: $95^{\circ} \mathrm{C}$ for $1 \mathrm{~min}$, followed by 40 cycles of amplification with denaturation at $95^{\circ} \mathrm{C}$ for $15 \mathrm{~s}$, annealing at $65^{\circ} \mathrm{C}$ for $30 \mathrm{~s}$, extension at $72^{\circ} \mathrm{C}$ for $30 \mathrm{~s}$ and then fluorescent signal collection at $82^{\circ} \mathrm{C}$ for $15 \mathrm{~s}$. Serial dilutions of plasmid DNA carrying the open reading frame (ORF) of UII and UT obtained from grouper were used as the standards for data calibration. As an internal control, a real-time PCR for 18S rRNA was also conducted in each experiment. The quantitative results were normalized as a ratio of the target gene:18S expression level.

\section{Synthesis of the mature peptide of the orange-spotted grouper UII and urantide}

The putative mature peptide of grouper UII with the AGNSECFWKYCV sequence was chemically synthesized by Invitrogen. Urantide, a specific antagonist of UT,

Published by Bioscientifica Ltd. 
with the H-Glu-c[Pen-Phe-DTrp-Orn-Tyr-Cys]-Val-OH sequence, was also synthesized by the same company. Each peptide was lyophilized and stored at $-80^{\circ} \mathrm{C}$ until use. Before the experiments, each peptide was dissolved in $1 \times \mathrm{PBS}$ at a concentration of $10^{-3} \mathrm{M}$ as stock solution.

\section{Functional confirmation of UII and UT of the orange-spotted grouper}

The ORF of grouper UT was subcloned into pcDNA3.1/ Zeo(-) (Invitrogen) to generate the UT expression vector pcDNA3.1/Zeo(-).gUT for functional expression in HEK293 cells. The HEK293 cells were cultured for $24 \mathrm{~h}$ on poly-D-lysine-coated coverslips at a density of $0.035 \times$ $10^{6}$ cells $/ 1 \mathrm{ml}$ per coverslip. On the next day, transient transfection was carried out for $6 \mathrm{~h}$ in $1 \mathrm{ml}$ OPTI-MEM with $1 \mu \mathrm{g}$ pcDNA3.1/Zeo(-).gUT and $5 \mu$ Lipofectamine 2000 (Invitrogen). After transfection, the cells were recovered for $18-24 \mathrm{~h}$ in DMEM with $10 \%(\mathrm{v} / \mathrm{v})$ FBS at $37^{\circ} \mathrm{C}$ under $5 \% \mathrm{CO}_{2}$ and saturated humidity. The transfected cells were then preloaded with the $\mathrm{Ca}^{2+}$ sensitive dye Fluo3/AM ( $2 \mu \mathrm{M}$, Molecular Probes, Eugene, OR, USA) for $40 \mathrm{~min}$ at $37^{\circ} \mathrm{C}$ in $\mathrm{HBSS}(142 \mathrm{mM} \mathrm{NaCl}$, $5.6 \mathrm{mM} \mathrm{KCl}, 0.44 \mathrm{mM} \mathrm{K}_{2} \mathrm{HPO}_{4}, 1.0 \mathrm{mM} \mathrm{MgCl}, 0.34 \mathrm{mM}$ $\mathrm{Na}_{2} \mathrm{HPO}_{4}, 2 \mathrm{mM} \mathrm{CaCl}, 5.6 \mathrm{mM}$ glucose, and $10 \mathrm{mM}$ HEPES; pH 7.4) in the dark at room temperature. After incubation, the cultured cells were washed three times with HBSS and then transferred into a homemade chamber. $\left[\mathrm{Ca}^{2+}\right] \mathrm{i}$ measurements at the single-cell level were conducted at room temperature $\left(\sim 22^{\circ} \mathrm{C}\right)$ in a Leica confocal system (Leica Microsystems Heidelberg GmbH, Germany). Excitation wavelengths were set to $488 \mathrm{~nm}$, whereas the emission wavelength was fixed at $510 \mathrm{~nm}$. Test substances were introduced gently into the imaging chamber with cell culture by hand pipetting. For studies under $\mathrm{Ca}^{2+}$-free conditions, the old medium was replaced with HBSS buffer prepared without $\mathrm{CaCl}_{2}$ and supplemented with $2 \mathrm{mM}$ EGTA. Intracellular $\mathrm{Ca}^{2+}$ data are expressed as the florescence signals at $510 \mathrm{~nm}$ triggered by $488 \mathrm{~nm}$ excitation (referred to as florescence amplitude).

\section{In vivo effects of UII via i.p. injection on the mRNA expression of hormones of growth regulation}

Grouper with BWs of 50-55 g were allowed to acclimatize for 2 weeks in a recirculating seawater system at an ambient temperature under natural photoperiod conditions. The fish were fed two times daily (0900 and $1600 \mathrm{~h}$ ) with commercial pellets until satiety and starved for $24 \mathrm{~h}$ before i.p. injection. The synthesized UII dissolved in distilled $1 \times$ PBS was injected i.p. at dosages of $10 \mathrm{ng}, 100 \mathrm{ng}$, and $1000 \mathrm{ng} / \mathrm{g}$ BW. For the control group of each time point, grouper received injections of an appropriate volume of $1 \times$ PBS based on the BW of the individual fish. The dosage was selected based on our previous validation. Each fish received only one injection at the onset of the experiments $(0900 \mathrm{~h})$. At different time points $(0,3,6$, and $12 \mathrm{~h})$ after i.p. injection, the fish were killed by decapitation. Tissues, including hypothalamus, pituitary, and liver, of each fish were quickly removed and snap-frozen in liquid nitrogen. After RNA extraction and reverse transcription, a real-time PCR was carried out to determine the mRNA expression of $g h r h$, ss1, $s s 2, g h, g h r 1, g h r 2, i g f 1$, and igf2. Real-time PCRs were carried out on the LightCycler 480 Sequence Detection System (Roche) using a LightCycler 480 SYBR Green I Master Kit (Roche). All the primers used in this study are listed in Supplementary Table 1 . The PCRs were conducted with the following thermal cycling parameters: $95^{\circ} \mathrm{C}$ for $10 \mathrm{~min}$, followed by 40 cycles of amplification with denaturation at $95^{\circ} \mathrm{C}$ for $10 \mathrm{~s}$, annealing at $58^{\circ} \mathrm{C}$ for $15 \mathrm{~s}$, extension at $72^{\circ} \mathrm{C}$ for $30 \mathrm{~s}$, and then fluorescent signal collection at $80^{\circ} \mathrm{C}$ for $5 \mathrm{~s}$. Serial dilutions of plasmid DNA carrying the ORF of these target genes of grouper were used as the standards for data calibration. As an internal control, a real-time PCR for $18 \mathrm{~S}$ rRNA was also conducted in each experiment. The quantitative results were normalized as a ratio of the target gene/18S expression level.

\section{Data transformation and statistical analysis}

Quantitative data are presented as means \pm s.E.M. Significant differences in the tissue distribution and i.p. injection studies were estimated by one-way ANOVA followed by Duncan (D)'s tests. A $P$ value of $<0.05$ was considered significant. Statistical analysis was carried out using the Statistical Package for the Social Sciences, version 17.0 (SPSS, Inc.).

\section{Results}

\section{Molecular cloning and characterization of UII and UT}

The full-length cDNAs of the UII precursor (GenBank: FJ751245.1) and UT (GenBank: FJ751245.1) were successfully isolated from CNSS and spinal cord tissue samples of grouper respectively. The cDNA of UII is $966 \mathrm{bp}$ in length with a 57 bp 5'UTR, a 519 bp 3'UTR, and a 387 bp ORF encoding 129 amino acids. The deduced 129 amino acids precursor protein encompasses a 21 amino acids signal peptide, a 96 amino acids $\mathrm{N}$-terminal flanking peptide, and

Published by Bioscientifica Ltd. 
a 12 amino acids UII mature peptide (predicted by SignalP 3.0 and ProP 1.0). The Lys ${ }^{116}-\operatorname{Arg}^{117}$ residues adjacent to the UII $\mathrm{N}$ terminus indicate a potential enzymatic cleavage site (Fig. 1). The N-terminal region of UII is highly variable among fish and mammals, whereas the C-terminal amino acids, which are organized in a disulfide-linked cycle array, c[cys-Phe-Trp-Lys-Tyr-Cys], are continuously conserved among different species (Fig. 1). The full-length cDNA of UT is $1461 \mathrm{bp}$ in length with a $1071 \mathrm{bp}$ ORF, an 84 bp 5'UTR, and a 309 bp 3'UTR. The ORF encodes 357 amino acids containing a short $\mathrm{N}$-terminal ectodomain, seven transmembrane domains (TMDs) joined by alternating extra- and intracellular loops, and a C-terminal region (Fig. 2). The seven TMDs (referred to as TMD1-7) cover positions 27-49, 62-84, 99-121, 142-164, 189-211, 238-260, and 280-302 of the protein sequence. A conserved aspartic acid $\left(\mathrm{D}^{71}\right)$ residue and two conserved Cys $\left(\mathrm{C}^{97}\right.$ and $\mathrm{C}^{178}$ ) residues could be identified in the sequence. The (E/D) RY motif and NPx2-3Y motif were also mapped in this protein (Fig. 2).

\section{Tissue distribution profiles of UII and UT}

To establish the tissue expression profiles of UII and UT in grouper, the mRNA expression of these two genes was examined by real-time PCR (Fig. 3). The expression of UII and UT was detected in all the tissues examined, and both these genes were expressed in the CNSS and CNS, including the spinal cord, pituitary, forebrain, midbrain, hindbrain and hypothalamus, and the ovary at very high levels. Compared with its expression in the CNSS $(\mathrm{UII} / 18 \mathrm{~S}=3.263750257)$, the expression levels of UII were extremely low in the heart $\left(\mathrm{UII} / 18 \mathrm{~S}=7.02869 \times 10^{-7}\right)$, kidney $\left(\mathrm{UII} / 18 \mathrm{~S}=9.14547 \times 10^{-8}\right)$, spleen $(\mathrm{UII} / 18 \mathrm{~S}=$ $\left.1.60515 \times 10^{-7}\right)$, and gill $\left(\mathrm{UII} / 18 \mathrm{~S}=3.22844 \times 10^{-7}\right)$ (Fig. 3A). In this study, the ovary was found to be the major site of UT expression in grouper. In addition, UT was also found to be highly expressed in the CNSS and hypothalamus, and lower expression of UT was observed in peripheral tissues, including the heart, kidney, spleen, rectum, and gill (Fig. 3B). The expression of UII and UT in the liver of grouper was confirmed by RT-PCR using gene-specific primers (the same primers used in real-time PCR) for UII and UT (Supplementary Figure 2, see section on supplementary data given at the end of this article).

\section{Functional expression of grouper UT in HEK293 cells}

In HEK293 cells transfected with pcDNA3.1/Zeo(-).gUT, UII treatment $(0.4 \mathrm{nM})$ was effective in triggering a rapid

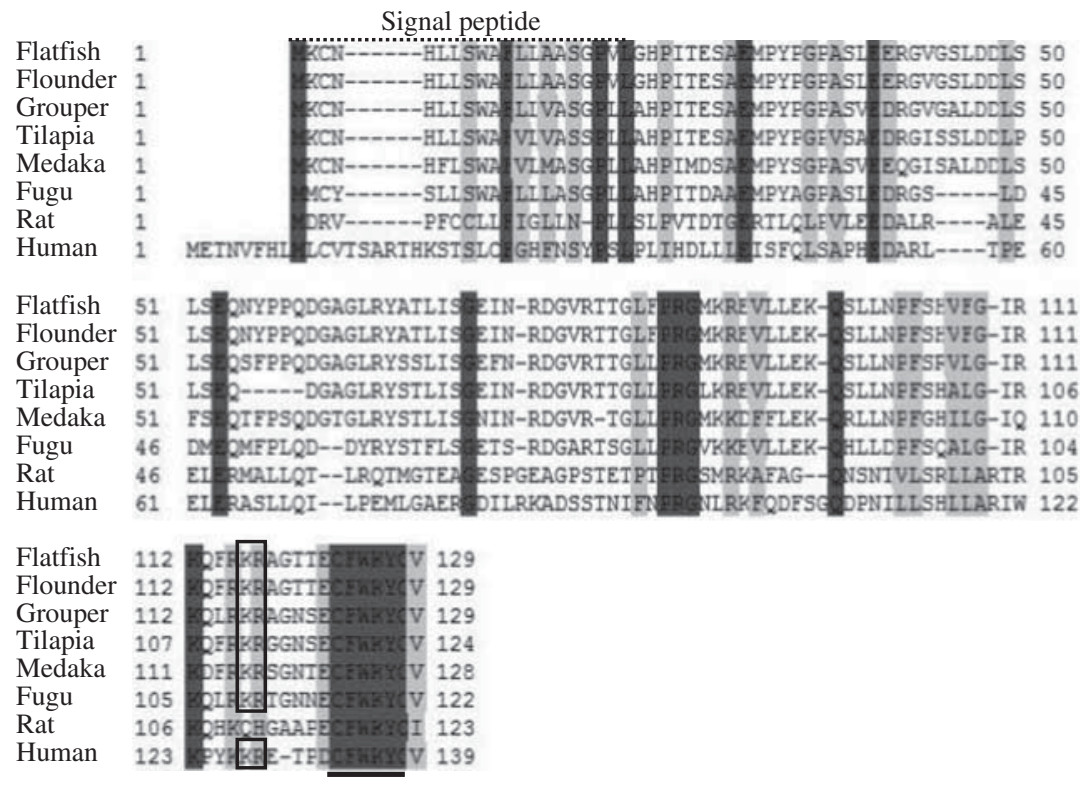

Figure 1

Alignment of orange-spotted grouper UII precursor with the amino acid sequences of its counterparts reported in other species. The sequences used for UII precursor alignment were from flatfish (GenBank: CAD56908.1), flounder (GenBank: CAD56908.1), grouper (GenBank: ACN65410.1), tilapia (GenBank: XP_003438987.1), medaka (GenBank: XP_004070888.1), fugu (GenBank: CAI63878.1), rat (GenBank: NP_036040.1), and human
(GenBank: AAD55577.1). The amino acid residues that are identical among the compared vertebrates are shaded in black, while the conserved amino acid residues are shaded in gray. The region covering the signal peptide is marked with a dotted line. The highly conserved, cyclic disulfide-linked structure across species is delineated with a solid line. The Lys-Arg dibasic site for the potential proteolytic cleavage is boxed with a solid line.

Published by Bioscientifica Ltd. 


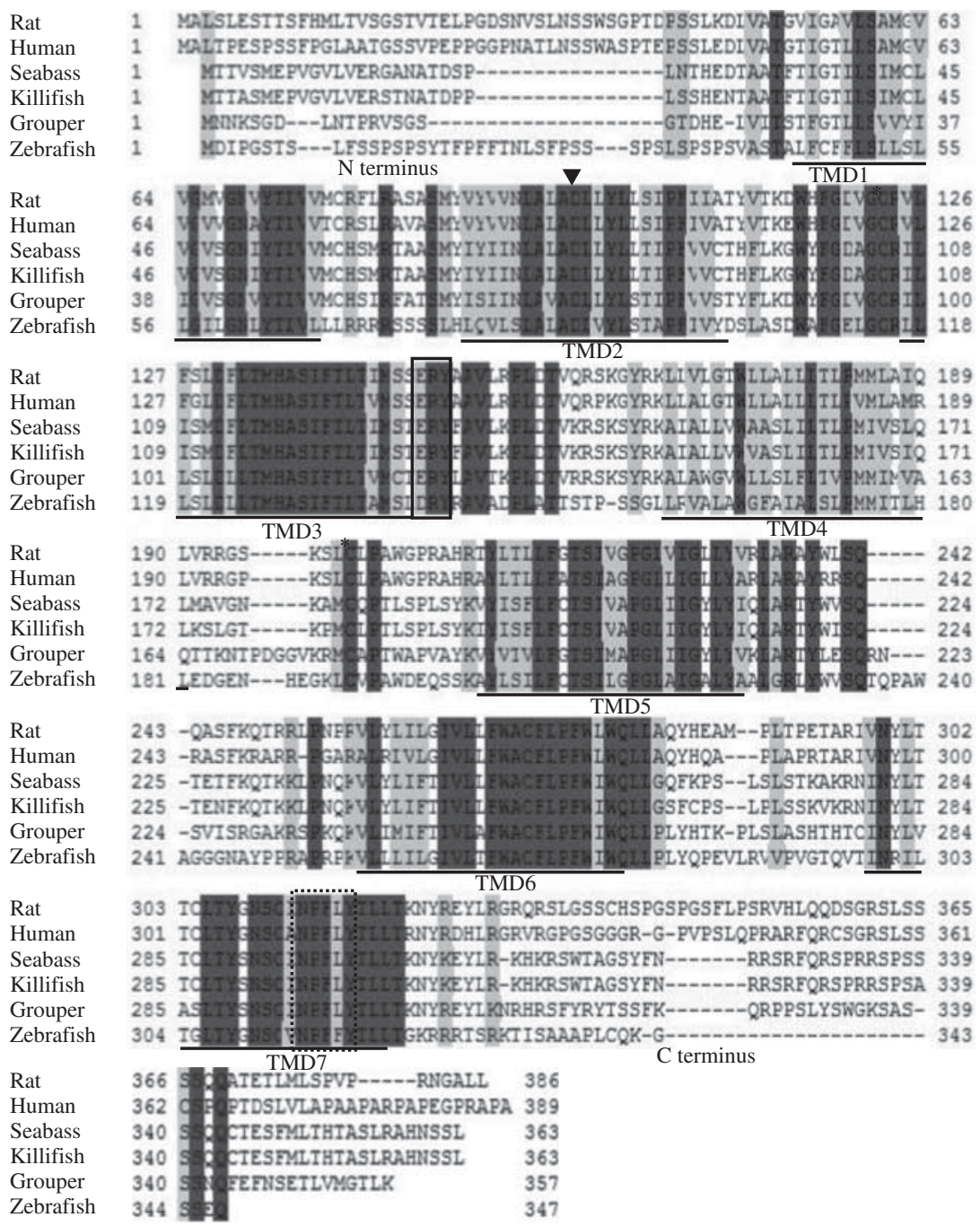

\section{Figure 2}

Alignment of orange-spotted grouper UII receptor (UT) with the amino acid sequences of its counterparts reported in other species. The sequences used for UT alignment were from rat (GenBank: NP_065412.1), human (GenBank: NP_061822.1), European seabass (GenBank: CBN81173.1), killifish (GenBank: AEG64705.1), grouper (GenBank: ACN65411.1), and

rise in intracellular free $\mathrm{Ca}^{2+}$ levels $\left(\left[\mathrm{Ca}^{2+}\right]\right.$; Fig. $\left.4 \mathrm{~A}\right)$. However, this $\mathrm{Ca}^{2+}$ response was not observed following UII treatment in HEK293 cells transfected with the blank vector pcDNA3.1/Zeo(-) (Fig. 4C). Moreover, when the cells transfected with pcDNA3.1/Zeo(-).gUT were pretreated with urantide $(1 \mu \mathrm{M})$, a specific antagonist of UT, for $15 \mathrm{~min}$, UII $(0.4 \mathrm{nM})$ could not stimulate $\left[\mathrm{Ca}^{2+}\right] \mathrm{i}$ mobilization (Fig. 4B). In a parallel experiment, in HEK293 cells transfected with pcDNA3.1/Zeo(-).gUT, UII $(1 \mathrm{nM})$ also significantly induced $\left[\mathrm{Ca}^{2+}\right]$ i mobilization (Fig. 4D). Moreover, when the cells were treated in $\mathrm{Ca}^{2+}$-free medium, both basal $\left[\mathrm{Ca}^{2+}\right] \mathrm{i}$ and sustained zebrafish (GenBank: XP_001335317.1). The seven transmembrane domains are each delineated with a solid line. The conserved aspartic acid (D) residue is indicated with an inverted small triangle and the two conserved Cys (C) are each marked with an asterisk $\left(^{*}\right)$. The (E/D) RY motif is boxed with a solid line and the NPx2-3Y motif is boxed with a dotted line.

$\mathrm{Ca}^{2+}$ levels followed by the $\mathrm{Ca}^{2+}$ peak induced by UII treatment $(1 \mathrm{nM})$ were remarkably suppressed, while the $\mathrm{Ca}^{2+}$ peak was not effected (Fig. 4E). Moreover, after the removal of extracellular $\mathrm{Ca}^{2+}$ using $\mathrm{Ca}^{2+}$-free medium and depletion of the intracellular $\mathrm{Ca}^{2+}$ stores using thapsigargin, UII $(1 \mathrm{nM})$ could not stimulate any $\mathrm{Ca}^{2+}$ response (Fig. 4F). A previous study has reported that SS14 can activate rat UT to induce $\mathrm{Ca}^{2+}$ mobilization in HEK293 cells (Liu et al. 1999). A similar phenomenon was also observed in this study. Both UII (1 nM) and SS14 $(1 \mathrm{nM})$ triggered $\left[\mathrm{Ca}^{2+}\right] \mathrm{i}$ mobilization, but the shapes of the two $\left[\mathrm{Ca}^{2+}\right] \mathrm{i}$ traces were quite different (Fig. 5).

Published by Bioscientifica Ltd. 

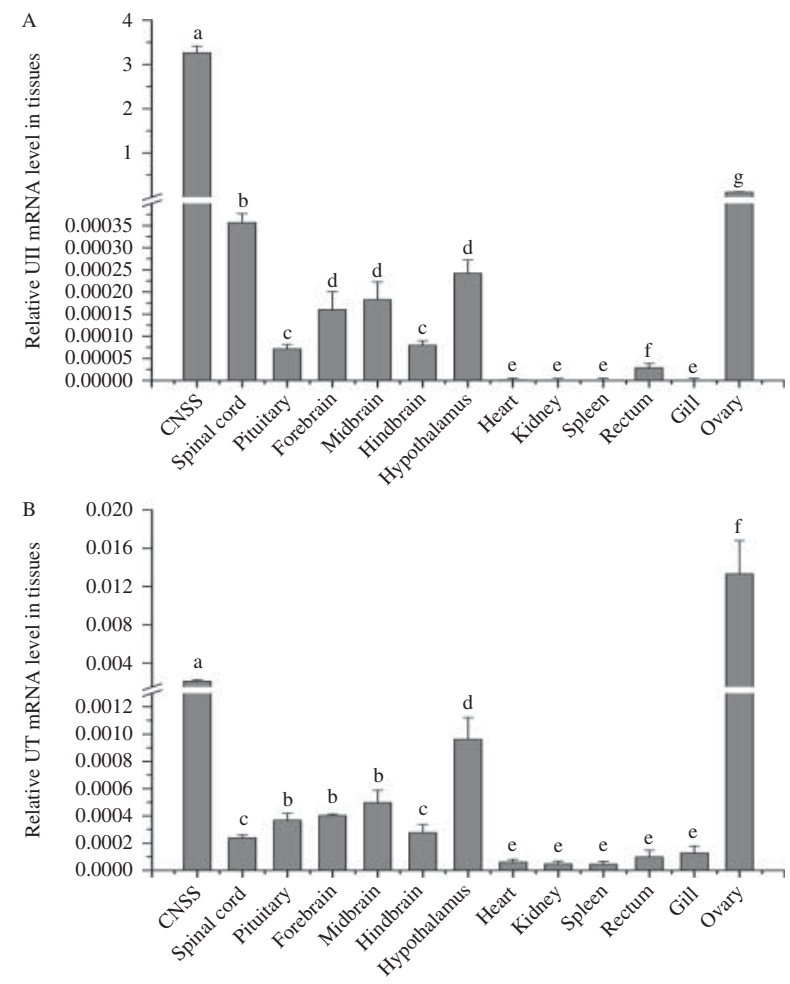

Figure 3

Tissue distribution of the UII (A) and UT (B) genes in the orange-spotted grouper. The tissues examined in the present study are as follows: CNSS, spinal cord, pituitary, forebrain, midbrain, hindbrain, hypothalamus, heart, kidney, spleen, rectum, gill, and ovary. Three sets of first-strand cDNA from samples of each tissue were used as templates in this study. The 18S rRNA was used as an internal control, and all quantitative results were normalized to the ratio of the target gene: $18 \mathrm{~S}$ expression levels. The data are presented as means \pm s.E.M. $(n=9)$. The statistical differences were estimated using one-way ANOVA followed by Duncan (D)'s multiple range test $(P<0.05)$. Groups with different letters display a significant difference $(P<0.05)$.

The $\mathrm{Ca}^{2+}$ response induced by UII was biphasic with a peak after UII stimulation followed by a sustained stage (Fig. 5A), while the $\mathrm{Ca}^{2+}$ mobilization triggered by SS14 was fast and transitory (Fig. 5B).

\section{Effects of UII on the mRNA expression of key hormones of growth regulation in grouper}

To determine the functions of UII in the regulation of growth in grouper, different doses of UII were administered to grouper via i.p. injections. In addition, samples of various tissues, including the hypothalamus, pituitary, and liver, of each fish were collected at the end point of each treatment and used for RNA extraction and firststrand cDNA preparation. The real-time PCR technique was used to detect the mRNA expression of $g h r h, s s 1$, and ss 2 in the hypothalamus, that of $g h$ in the pituitary, and

that of $g h r 1, g h r 2$, igf 1 , and $i g f 2$ in the liver. The results of the study showed that the i.p injection of UII at doses of 10 and $100 \mathrm{ng} / \mathrm{g}$ BW significantly stimulated the mRNA expression of $g h r h$ in the hypothalamus of grouper within $3 \mathrm{~h}$ (Fig. 6A). By contrast, the i.p. injection of UII at a dose of 100 and $1000 \mathrm{ng} / \mathrm{g}$ BW obviously inhibited the mRNA expression of $s s 1$ (Fig. 6B) and ss2 (Fig. 6C) and at a dose of $100 \mathrm{ng} / \mathrm{g}$ BW significantly inhibited the mRNA expression of $s s 1$ (Fig. 6B). No effect of UII on the expression of these three genes was observed at the other time points, including 6 and $12 \mathrm{~h}$ after UII injection (Fig. 6). In the pituitary of grouper, the i.p. injection of UII at doses of 100 and $1000 \mathrm{ng} / \mathrm{g}$ BW significantly stimulated the mRNA expression of $g h 6 \mathrm{~h}$ after injection (Fig. 6D) and that at a dose of $100 \mathrm{ng} / \mathrm{gBW}$ significantly increased the mRNA expression of $g h 12 \mathrm{~h}$ after injection (Fig. 6D). In the liver of grouper, the i.p. injection of UII at a dose of $10 \mathrm{ng} / \mathrm{g} \mathrm{BW}$ remarkably stimulated the mRNA expression of $g h r 1$ (Fig. 6E) and ghr2 (Fig. 6F) $12 \mathrm{~h}$ after injection and that of both igf1 (Fig. 6G) and igf2 (Fig. $6 \mathrm{H}$ ) $3 \mathrm{~h}$ after injection.

\section{Discussion}

In this study, we cloned the full-length cDNAs of UII and UT of the orange-spotted grouper. The amino acid alignment of the prepro-UII showed that the $\mathrm{C}$ terminus of this molecule, which contains the UII mature peptide, is the only domain that exhibits significant amino acid identity among the different species, whereas the $\mathrm{N}$ terminus is highly variable. This result is consistent with those observed in other vertebrates (Onan et al. 2004, Conlon 2008, Vaudry et al. 2010). The potential cleavage site for pro-hormone convertase is located at the Lys ${ }^{116}$ $\operatorname{Arg}^{117}$ position. Cleavage at this site generates a 12 amino acids peptide, which is the putative mature peptide of grouper UII. It is well documented that the length of the UII peptide is variable among the vertebrates, ranging from 11 amino acids in humans to 17 amino acids in mice, and the size of UII in fish that has been reported to date is 12 amino acids (Vaudry et al. 2010). The putative UT of grouper is composed of a short $\mathrm{N}$ terminus, seven TMDs joined by alternating extra- and intracellular loops, and a $\mathrm{C}$-terminal region. Two conserved cysteine residues $\left(\mathrm{C}^{97}\right.$ and $\mathrm{C}^{178}$, which are thought to form a conserved disulfide bridge that stabilizes the UT structure (Onan et al. 2004), and a conserved aspartic acid $\left(D^{71}\right)$ in TMD2 were found in this sequence. These are key signature residues of the rhodopsin family of GPCRs (Fredriksson et al. 2003). Moreover, an (E/D) RY motif, which follows TMD3, and an NPx2-3Y motif at the end of TMD7 were also identified

Published by Bioscientifica Ltd 

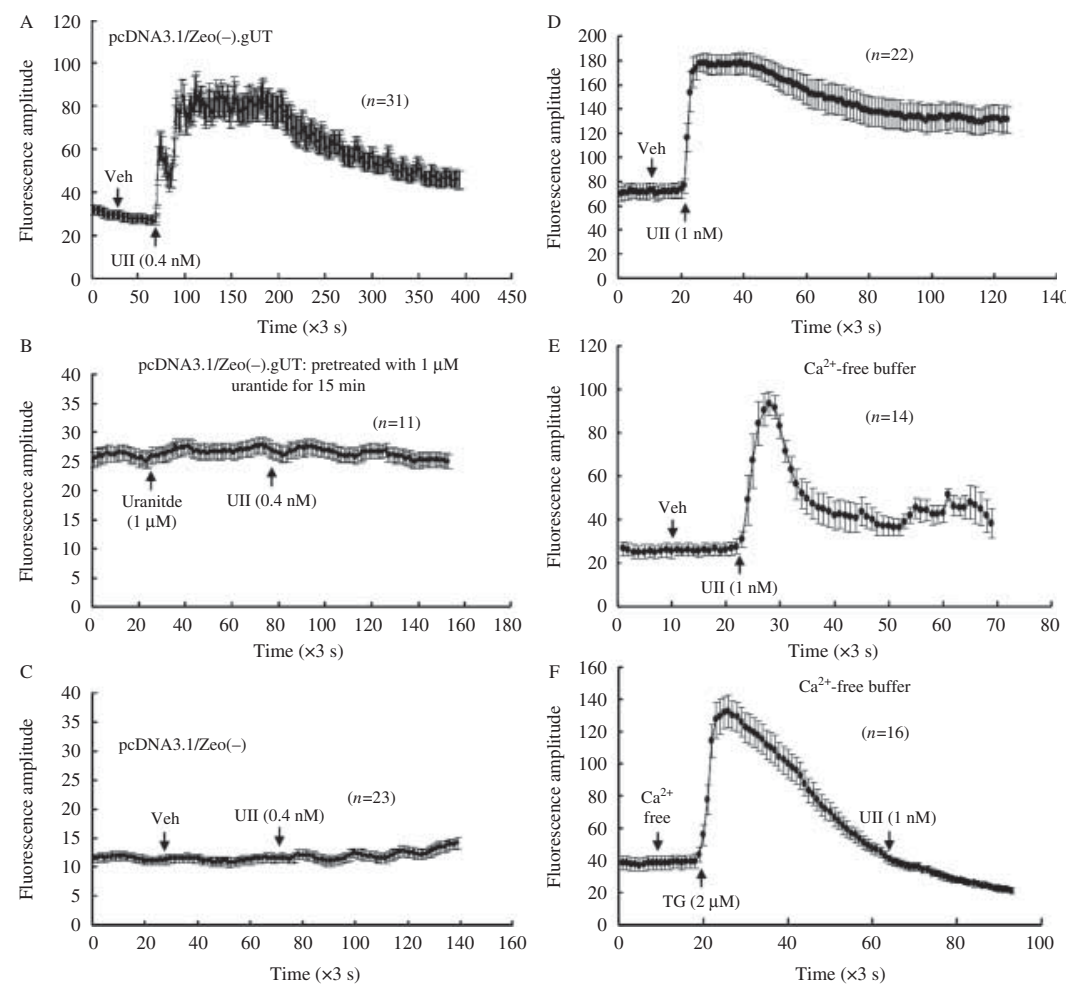

\section{Figure 4}

Functional coupling of orange-spotted grouper UT with $\mathrm{Ca}^{2+}$ mobilization in HEK293 cells. HEK293 cells were transiently transfected with the UT expression vector and preloaded with the $\mathrm{Ca}^{2+}$-sensitive dye Fluo3/AM ( $2 \mu \mathrm{M}$, Molecular Probes). After that, the cells were challenged with the vehicle (Veh; $1 \times$ PBS) for UII followed by treatment with 0.4 and $1 \mathrm{nM}$ UII respectively. $\mathrm{Ca}^{2+}$ traces for UT after stimulation with 0.4 and $1 \mathrm{nM}$ UII are shown in (A and D) respectively. In a parallel experiment, the cells were pretreated with urantide $(1 \mu \mathrm{M})$ for $15 \mathrm{~min}$, and then the cells were challenged with the same dose of urantide followed by treatment with a single dose of UII ( $0.4 \mathrm{nM})$. The $\mathrm{Ca}^{2+}$ trace after UII treatment is shown in (B). In another experiment, HEK293 cells transiently transfected with pcDNA3.1/ Zeo $(-)$ blank vector were treated with the vehicle $(1 \times$ PBS) followed by treatment with a single dose $(0.4 \mathrm{nM})$ of UII. The $\mathrm{Ca}^{2+}$ trace after UII treatment is shown in (C). In parallel experiments, to remove extracellular

in this sequence. The (E/D) RY motif is thought to be involved in the intracellular signal transduction of UT (Proulx et al. 2008). The NPx2-3Y motif is present in the seventh TMD of most of the GPCRs and may play a role in the agonist-induced receptor internalization (Naor et al. 1998).

Consistent with the results of previous studies in teleosts (Le Mevel et al. 2008), the CNSS is the major site of UII expression, although UII is also expressed at very high levels in the CNS. The detection of UII in the pituitary, forebrain, midbrain, and hindbrain in grouper is in accordance with the results obtained in flounder (Lu et al. 2006) and frogs (Coulouarn et al. 1998). Among the peripheral tissues, the highest expression of UII was observed in the ovary, and this result is different from the

$\mathrm{Ca}^{2+}$, the cells were treated with $\mathrm{Ca}^{2+}$-free medium (with 2 mM EGTA) and then challenged with a single dose of UII $(1 \mathrm{nM}) . \mathrm{Ca}^{2+}$ trace after stimulation with UII is shown in (E). Moreover, in another experiment, the cells were treated with $\mathrm{Ca}^{2+}$-free medium first and then challenged with $2 \mu \mathrm{M}$ thapsigargin (TG), followed by treatment with $1 \mathrm{nM}$ UII (F). Single-cell $\mathrm{Ca}^{2+}$ imaging was conducted in a Leica confocal system (Leica Microsystems Heidelberg GmbH, Mannheim, Germany). Excitation wavelength was set to $488 \mathrm{~nm}$ and the emission wavelength was fixed at $510 \mathrm{~nm}$. Intracellular $\mathrm{Ca}^{2+}$ data are expressed as the florescence signals at $510 \mathrm{~nm}$ triggered by $488 \mathrm{~nm}$ excitation (referred to as florescence amplitude). The fluorescence measurements in this study were taken every 3 seconds, as such the $x$-axis unit 'Time $(\times 3 \mathrm{~s})$ ' means that the real time for each point should be three times of the value shown on the $x$-axis.

results obtained in flounder, which exhibited the highest expression of UII in the rectum, even though the ovary was also found to be an important site of UII expression (Lu et al. 2006). However, in eels, UII was only detected in the CNSS using the RT-PCR technique (Nobata et al. 2011). Similar to the expression profile of UII, UT is abundantly expressed in the CNSS, CNS, and ovary in grouper. Moreover, the difference is that the ovary instead of the CNSS is the major site of UT expression. This result is quite consistent with the results obtained in flounder with the exception that the site with the highest expression of UT is the midbrain of flounder ( $\mathrm{Lu}$ et al. 2006). The mRNA expression of UII and UT in various fish tissues indicate that this peptide also has tissue-specific autocrine/

Published by Bioscientifica Ltd. 

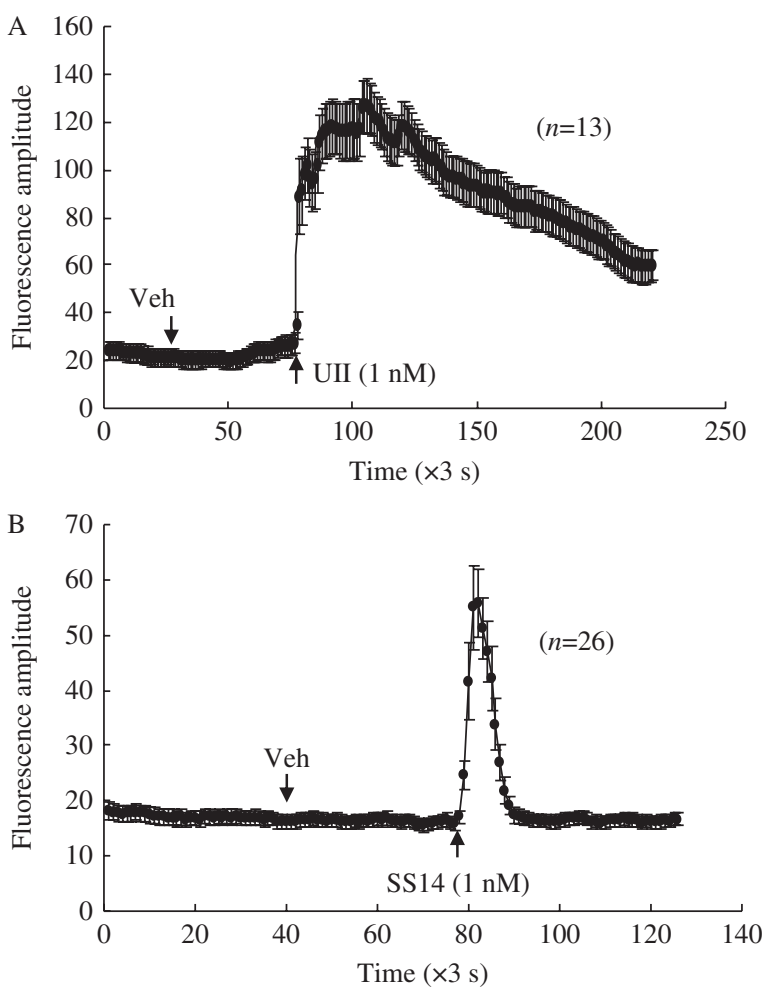

Figure 5

$\mathrm{Ca}^{2+}$ mobilization induced by UII and $\mathrm{SS} 14$ of the orange-spotted grouper in HEK293 cells transfected with UT. HEK293 cells were transiently transfected with the UT expression vector and preloaded with the $\mathrm{Ca}^{2+}$-sensitive dye Fluo3/AM ( $2 \mu \mathrm{M}$, Molecular Probes). After that, the cells were challenged with the vehicle (Veh; $1 \times$ PBS) for Ull followed by treatment with $1 \mathrm{nM}$ of UII (A) and $1 \mathrm{nM}$ of SS14 (B) respectively. Single-cell $\mathrm{Ca}^{2+}$ imaging was carried out in a Leica confocal system (Leica Microsystems Heidelberg GmbH, Germany). Excitation wavelength was set to $488 \mathrm{~nm}$ and the emission wavelength was fixed at $510 \mathrm{~nm}$. Intracellular $\mathrm{Ca}^{2+}$ data are expressed as the florescence signals at $510 \mathrm{~nm}$ triggered by $488 \mathrm{~nm}$ excitation (referred to as florescence amplitude). The fluorescence measurements in this study were taken every 3 seconds, as such the $x$-axis unit 'Time $(\times 3$ s)' means that the real time for each point should be three times of the value shown on the $x$-axis.

paracrine roles (Lu et al. 2006), which may involve growth and immune system, because there are reports of the mitogenic action of UII in human tumor cells (Zeng et al. 2006) and the immunomodulatory role of UII in teleosts (Singh \& Rai 2011). Interestingly, both UII and UT were found to be expressed in the ovary at very high levels in grouper, which implies that the UII/UT system may participate in the regulation of grouper reproduction. The results obtained in this study showed that $1 \mathrm{ng} / \mathrm{ml}$ $(0.72 \mathrm{nM})$ UII significantly induces the release of estradiol in the ovary of sexually-mature grouper, and this stimulatory effect is similar to that observed for treatment with human chorionic gonadotropin, which was used as a positive control in the experiments (Supplementary
Figure 1, see section on supplementary data given at the end of this article). Some studies in mammals have demonstrated that UT is expressed and UII is endogenously synthesized and locally released in human corpus cavernosum. In addition, the UII/UT system has been shown to be involved in erectile function (d'Emmanuele di Villa Bianca et al. 2010, Bianca et al. 2012). Because information on the effects of the UII/UT system on reproduction is limited in teleosts, the UII/UTinduced regulation of reproduction in grouper needs further investigation.

It is well known that the activation of UT by UII increases phosphoinositide turnover and subsequently triggers $\left[\mathrm{Ca}^{2+}\right]$ i mobilization (Ames et al. 1999, Lehner et al. 2007, Vaudry et al. 2010). In this study, the ability of the newly cloned UT to couple with $\mathrm{Ca}^{2+}$ mobilization was examined. The results showed that UII can significantly increase $\left[\mathrm{Ca}^{2+}\right]$ i levels and the UII-induced $\mathrm{Ca}^{2+}$ mobilization consists of two major components, including extracellular $\mathrm{Ca}^{2+}$ entry and $\mathrm{Ca}^{2+}$ release from intracellular stores. Given that UT exhibits high sequence identity with SSTRs (Marchese et al. 1995) and that both SS and cortistatin can activate UT at a much lower efficiency than UII to stimulate $\left[\mathrm{Ca}^{2+}\right]$ i mobilization (Liu et al. 1999), the effect of SS14 on $\mathrm{Ca}^{2+}$ mobilization in HEK293 cells with grouper UT was also investigated. The results showed that SS14 can significantly induce a fast and transitory increase in $\mathrm{Ca}^{2+}$ levels. This type of $\mathrm{Ca}^{2+}$ mobilization is quite different from that triggered by UII in that the UII-induced $\mathrm{Ca}^{2+}$ levels were sustained for a long time. These results indicate that SS can activate grouper UT to stimulate $\mathrm{Ca}^{2+}$ mobilization and that there is cross-reactivity between SS and UT.

As has been described in the Introduction, UII has mitogenic properties, and the UII/UT system acts as an autocrine/paracrine growth-stimulatory factor in the regulation of physiological actions in mammals (Vaudry et al. 2010, Gong et al. 2011). In the endocrine system, UII can regulate the secretion of various hormones in both fish and mammals (Vaudry et al. 2010), such as prolactin in fish (Rivas et al. 1986) and rats (Gartlon et al. 2001). Based on these results and the high expression levels of the UII/UT system in the hypothalamus and pituitary in grouper, we speculated that the UII/UT system may be involved in the regulation of the growth of grouper. In this study, we examined the effects of the i.p. injection of UII on the expression of major hormones that control growth and the hypothalamo-pituitary-liver axis in grouper. It is well known that GHRH is a major hypothalamic stimulator, whereas SS is a key inhibitor of GH synthesis and secretion in the pituitary gland (Sheridan \& Hagemeister

Published by Bioscientifica Ltd. 

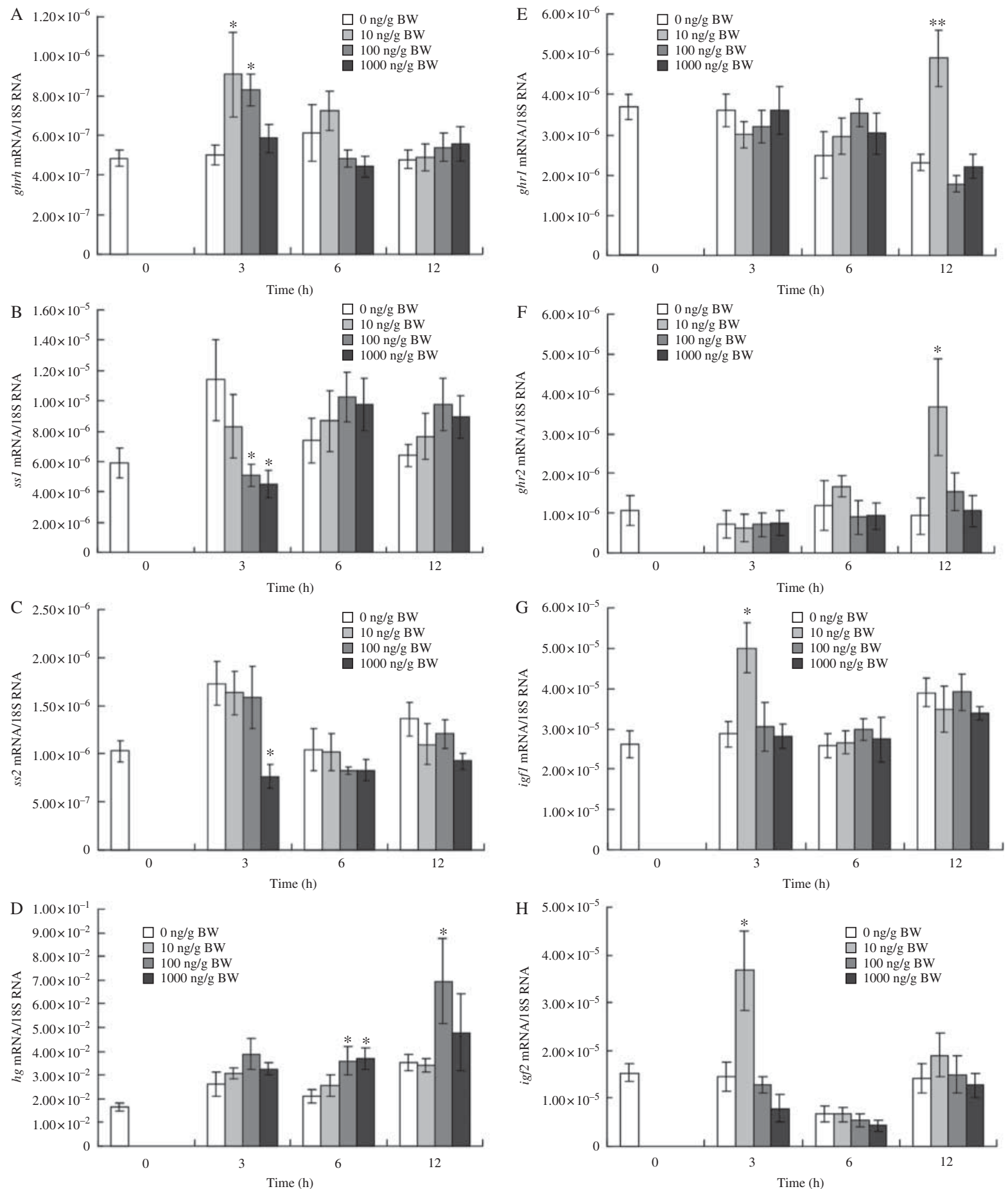

\section{Figure 6}

Effects of the i.p. injection of Ull on the mRNA expression of $g h r h(A), s s 1$ (B), and ss2 (C) in the hypothalamus, gh (D) in the pituitary, and ghr1 (E), ghr2 (F), igf1 (G), and igf2 (H) in the liver of the orange-spotted grouper. After 2 weeks of acclimatization, grouper received i.p. injections of $1 \times$ PBS or different doses of synthesized UII ( $10 \mathrm{ng}, 100 \mathrm{ng}$, and $1000 \mathrm{ng} / \mathrm{g} \mathrm{BW}$ ). Each fish was administered only one injection at the onset of the experiments. At a specific time point $(0,3,6$, or $12 \mathrm{~h}$ after i.p. injection), fish were killed and tissue

$\begin{array}{lr}\text { http://joe.endocrinology-journals.org } & \text { ○ } 2014 \text { Society for Endocrinology } \\ \text { DOI: } 10.1530 / \text { JOE-13-0282 } & \text { Printed in Great Britain }\end{array}$

samples of the hypothalamus, pituitary, and liver of each fish were collected for RNA extraction and reverse transcription. The mRNA expression of the genes was determined by real-time PCR. The $18 \mathrm{~S}$ rRNA was used as an internal control, and all the quantitative results were normalized to the ratio of the target gene: $18 \mathrm{~S}$ expression level. The data are presented as means \pm s.E.M. $(n=8-10)$. Statistical differences were estimated using one-way ANOVA followed by Duncan (D)'s multiple range test ( $\left.{ }^{*} P<0.05\right)$. 
2010, Reindl \& Sheridan 2012). In grouper, the full-length cDNAs of the ghrh precursor (Qian et al. 2012) and preprosomatostatin (Xing et al. 2005, Qian et al. 2012) have been cloned. Their expressions in the hypothalamus and the GHRH-induced stimulation of $g h$ mRNA expression and $\mathrm{GH}$ secretion in the pituitary have been confirmed (Xing et al. 2005, Qian et al. 2012). In the present study, UII exerted opposite effects on the mRNA expression of $g h r h, s s 1$, and $s s 2$, indicating that UII may participate in the regulation of $\mathrm{GH}$ synthesis and/or secretion at the level of the hypothalamus. A transient but noticeable increase in the basal ss 1 and ss 2 transcript levels was observed $3 \mathrm{~h}$ after the i.p. injection of UII (Fig. $6 \mathrm{~B}$ and $\mathrm{C}$ ). We do not know the exact mechanism that resulted in this phenomenon. Because UII was dissolved in the same $1 \times$ PBS that was used for the control group and the basal levels of SS1 and SS2 were stable at the other three time points studied $(0,6$, and $12 \mathrm{~h}$ after injection), we propose the hypothesis that the decrease in the mRNA levels of $s s 1$ and $s s 2$ is due to the administration of UII rather than due to a loss of the effect of PBS after UII treatment. The gene expression of $g h$ was found to be elevated 6 and $12 \mathrm{~h}$ after UII injection in the pituitary, and we suggest that this increase in $g h$ expression may be due to the stimulation of ghrh transcription and the suppression of ss 1 and ss 2 transcription $3 \mathrm{~h}$ after i.p. injection. The results obtained for the stimulation of $g h$ gene expression by UII are somewhat inconsistent with those of a previous in vitro study, which showed that UII had no significant effect on GH secretion in tilapia (Rivas et al. 1986). Thus, whether UII has an effect on GH release in the pituitary of grouper needs further investigation.

The biological actions of $\mathrm{GH}$ are mediated by the transmembrane GHRs. In fish and other vertebrates, the expression of GHRs is most abundant in the liver. Multiple GHRs derived from distinct mRNAs have been described in many species of fish; however, it is not yet clear whether these GHRs have similar or distinct functions (Saera-Vila et al. 2007). Two distinct cDNAs of $g h r 1$ and $g h r 2$ were cloned from grouper, and the expression levels of Ghr1 in the liver were much higher than those of Ghr2 (Li et al. 2007). This phenomenon is consistent with the results obtained in the present study: the basal level (control group received injections of $1 \times$ PBS instead of UII) of Ghr1 expression was 2- to 3.5-fold higher than that of Ghr2 expression in the liver. Moreover, the expression of both Ghr1 and Ghr2 was significantly increased $12 \mathrm{~h}$ after UII injection. Because the stimulation and inhibition of Ghrh and Ss1/Ss2 expression by UII respectively were observed $3 \mathrm{~h}$ after i.p. injection, the stimulation of $\mathrm{Gh}$ expression by UII was observed 6 and $12 \mathrm{~h}$ after injection, and the GH-induced GHR expression in the liver is a welldocumented phenomenon in mammals (Gonzalez et al. 2007, Jiang et al. 2007), we speculated that the stimulation of Ghr1 and Ghr2 expression by UII is the result of the increase in GH levels in the pituitary. GH is the principal regulator of IGF synthesis, and GH treatment in vivo and in vitro stimulates the mRNA expression of IGF1 and IGF2 in a variety of tissues, including those of fish and other vertebrates (Reindl \& Sheridan 2012). IGF2 is considered to be a primary growth factor required for early development, whereas IGF1 is required to achieve maximal growth. In the present study, UII stimulated the mRNA expression of both igf 1 and igf $23 \mathrm{~h}$ after UII injection, which indicates that UII may regulate the expression of igf mRNA at different growth stages of grouper. Because IGF levels were elevated just $3 \mathrm{~h}$ after UII injection, to determine whether the stimulation of igf transcription by UII is a consequence of the increase in GH levels in the pituitary or a direct effect of UII in the liver, primary liver cells of grouper were challenged with different doses of UII at 3 and $6 \mathrm{~h}$ respectively. However, UII showed no significant effect on the mRNA expression of both Igf1 and Igf2 at any dose or any time point (Supplementary Figure 3, see section on supplementary data given at the end of this article), which indicates that UII cannot exert a direct effect on igf1 and igf2 gene transcription. Because, in addition to $\mathrm{GH}$, other hormones, such as insulin, SS, cortisol, and thyroid hormones, can also influence igf mRNA expression in the liver and extrahepatic tissues (Reindl \& Sheridan 2012) and UII is known to regulate the secretion of various hormones, such as prolactin, TSH (Gartlon et al. 2001), and insulin (Silvestre et al. 2001), we cannot exclude the possibility that UII indirectly stimulates igf mRNA expression through the regulation of other hormones in the liver. Collectively, these results delineate the hypothetical regulation of the transcription of genes encoding major hormones controlling growth in grouper by UII: after the i.p. injection of UII in grouper, UII simulated the mRNA expression of $g h r h$, simultaneously inhibited the mRNA expression of ss1 and ss 2 in the hypothalamus, and subsequently induced GH synthesis and secretion in the pituitary. The increased GH level exerts its stimulatory effect through circulation on the transcription of $g h r 1$ and $g h r 2$ and subsequently induces the synthesis and secretion of IGFs. On the other hand, UII may indirectly upregulate the expression of liver igf mRNA by regulating other hormones. The increase in the levels of IGFs finally results in the promotion of the growth of grouper. Because we only examined the effects of UII on

Published by Bioscientifica Ltd 
the mRNA expression of these genes and because the release of hormones, such as GH, may occur rapidly without changes in gene expression, future experiments, including measurements of the secretion of hormones, such as GH in the pituitary and IGFs in the liver, after UII injection, and in vitro studies of the synthesis of these genes and the secretion of the gene products in primary hypothalamic cells, pituitary cells, and liver cells, and the testing of other important genes that are known to control growth in fish, such as pacap and ghrelin, may be helpful to verify this hypothesis.

A previous study has reported that a time-dependent increase in the internalization of UT expressed in COS-7 cells is observed after the binding of UII (Proulx et al. 2005). An analysis of consecutive administrations of UII in human endothelial cells has shown that the response to the second administration of UII is smaller than that to the first administration, which indicates the occurrence of desensitization (Brailoiu et al. 2008). These results indicate that, similar to most GPCRs, UT is also subject to desensitization. In this study, the analysis of the regulation of the expression of genes involved in the somatotropic axis by UII revealed that most of the responses, including those of ghrh, ghr1, ghr2, igf1, and igf2, were 'bell shaped' and, with an increase in the dose and/or time, the stimulatory response was dismissed completely. One reason for this phenomenon may be the desensitization of UT. A recent in vitro study has demonstrated that high doses $(1 \mu \mathrm{M})$ of UII and UII-related peptide (URP) are capable of specifically activating two SSTRs, SSTR 2 and SSTR5, and mimicking the effects of SS on its cognate receptors in CHO-K1 cells (Malagon et al. 2008). In our previous study, four types of SSTRs, including SSTR1, SSTR2, SSTR3, and SSTR5, have been detected in the CNS, pituitary, and liver of the orangespotted grouper (Haiyan et al. 2010). Therefore, we cannot exclude the possibility that UII activated SSTRs in the present study. However, given that: i) it is well known that SS inhibits the production and release of GH and IGF1 at the pituitary and liver levels respectively in fish (Sheridan \& Hagemeister 2010), and ii) our in vitro study showed that SS14 can inhibit GH release but has no effect on the mRNA expression of $g h$ in the pituitary of grouper, then it is possible that SS14 can significantly inhibit the mRNA expression of $g h r 1, g h r 2, i g f 1$, and igf2 in liver cells (B Wang, C Qin, W Li, 2013, unpublished observations). If an effect similar to that described by Malagon et al. (2008) happened in this study, UII should have similar effects to those of SS on the expression of $g h$ (no effect or inhibition), ghr1/ghr2, and igf1/igf2 (inhibition) in our in vivo study. Based on these reasons, we speculated that UII regulated the mRNA expression of these genes in our in vivo study mainly by binding to UT.

In summary, the full-length cDNAs of UII and UT were cloned and characterized in grouper. Our in vitro study showed that both UII and SS14 can trigger $\left[\mathrm{Ca}^{2+}\right] \mathrm{i}$ mobilization in HEK293 cells transfected with grouper UT, but the types of $\left[\mathrm{Ca}^{2+}\right] \mathrm{i}$ traces triggered by the two peptides are quite different. The in vivo study indicated that UII might act as a stimulatory factor in the promotion of the growth of grouper. Our ongoing research will focus on in vivo and in vitro studies to further define the role of the UII/UT system in the regulation of growth of the orange-spotted grouper.

\section{Supplementary data}

This is linked to the online version of the paper at http://dx.doi.org/10.1530/ JOE-13-0282.

\section{Declaration of interest}

The authors declare that there is no conflict of interest that could be perceived as prejudicing the impartiality of the research reported.

\section{Funding}

This research was supported by the National Natural Science Foundation of China (31101879, 31072194, and 31272639), the National Basic Research 973 program (2004CB117402 and 2010CB126302), the National '863' Development Project (2007AA091404), and the Fundamental Research Funds for the Central Universities to Dr W L.

\section{Author contribution statement}

C S was in charge of the sequence analysis and functional expression, i.p. injection, ovary fragment and liver cell culture, and target gene detection studies and wrote the manuscript. D D and $H D$ carried out the molecular cloning and tissue distribution studies. B L, C Q, J J, and B W contributed to the i.p. injection and target gene expression experiments. $\mathrm{W} L$ was the $\mathrm{PI}$ who contributed to the conception and design of the research.

\section{Acknowledgements}

The authors are grateful to Miss Jinkai Qing for her help with the construction of the expression vector of UT and to Miss Minxuan Wang for her help with the confirmation of UII/UT expression in the liver of grouper.

\section{References}

Ames RS, Sarau HM, Chambers JK, Willette RN, Aiyar NV, Romanic AM, Louden CS, Foley JJ, Sauermelch CF, Coatney RW et al. 1999 Human urotensin-II is a potent vasoconstrictor and agonist for the orphan receptor GPR14. Nature 401 282-286. (doi:10.1038/45809)

Bern HA, Pearson D, Larson BA \& Nishioka RS 1985 Neurohormones from fish tails: the caudal neurosecretory system. I. "Urophysiology" and the 
caudal neurosecretory system of fishes. Recent Progress in Hormone Research 41 533-552.

Bianca R, Mitidieri E, Fusco F, D'Aiuto E, Grieco P, Novellino E, Imbimbo C, Mirone V, Cirino G \& Sorrentino R 2012 Endogenous urotensin II selectively modulates erectile function through eNOS. PLOS ONE 7 e31019. (doi:10.1371/journal.pone.0031019)

Brailoiu E, Jiang X, Brailoiu GC, Yang J, Chang JK, Wang H \& Dun NJ 2008 State-dependent calcium mobilization by urotensin-II in cultured human endothelial cells. Peptides 29 721-726. (doi:10.1016/j.peptides. 2007.12.019)

Conlon JM 2008 Liberation of urotensin II from the teleost urophysis: an historical overview. Peptides 29 651-657. (doi:10.1016/j.peptides.2007. 04.021)

Conlon JM, O'Harte F, Smith DD, Tonon MC \& Vaudry H 1992 Isolation and primary structure of urotensin II from the brain of a tetrapod, the frog Rana ridibunda. Biochemical and Biophysical Research Communications 188 578-583. (doi:10.1016/0006-291X(92)91095-8)

Coulouarn Y, Lihrmann I, Jegou S, Anouar Y, Tostivint H, Beauvillain JC, Conlon JM, Bern HA \& Vaudry H 1998 Cloning of the cDNA encoding the urotensin II precursor in frog and human reveals intense expression of the urotensin II gene in motoneurons of the spinal cord. PNAS 95 15803-15808. (doi:10.1073/pnas.95.26.15803)

Coulouarn Y, Jegou S, Tostivint H, Vaudry H \& Lihrmann I 1999 Cloning, sequence analysis and tissue distribution of the mouse and rat urotensin II precursors. FEBS Letters 457 28-32. (doi:10.1016/S00145793(99)01003-0)

Do-Rego JC, Chatenet D, Orta MH, Naudin B, Le Cudennec C, Leprince J, Scalbert E, Vaudry H \& Costentin J 2005 Behavioral effects of urotensin-II centrally administered in mice. Psychopharmacology 183 103-117. (doi:10.1007/s00213-005-0140-2)

d'Emmanuele di Villa Bianca R, Cirino G, Mitidieri E, Coletta C, Grassia G, Roviezzo F, Grieco P, Novellino E, Imbimbo C, Mirone V et al. 2010 Urotensin II: a novel target in human corpus cavernosum. Journal of Sexual Medicine 7 1778-1786. (doi:10.1111/j.1743-6109.2009. 01450.x)

Evans DH, Hyndman KA, Cornwell E \& Buchanan P 2011 Urotensin II and its receptor in the killifish gill: regulators of $\mathrm{NaCl}$ extrusion. Journal of Experimental Biology 214 3985-3991. (doi:10.1242/jeb.065243)

Fredriksson R, Lagerstrom MC, Lundin LG \& Schioth HB 2003 The G-protein-coupled receptors in the human genome form five main families. Phylogenetic analysis, paralogon groups, and fingerprints. Molecular Pharmacology 63 1256-1272. (doi:10.1124/mol.63.6.1256)

Gartlon J, Parker F, Harrison DC, Douglas SA, Ashmeade TE, Riley GJ, Hughes ZA, Taylor SG, Munton RP, Hagan JJ et al. 2001 Central effects of urotensin-II following ICV administration in rats. Psychopharmacology 155 426-433. (doi:10.1007/s002130100715)

Gong H, Ma H, Liu M, Zhou B, Zhang G, Chen Z, Jiang G, Yan Y, Yang C, Kanda M et al. 2011 Urotensin II inhibits the proliferation but not the differentiation of cardiac side population cells. Peptides 32 1035-1041. (doi:10.1016/j.peptides.2011.01.024)

Gonzalez L, Curto LM, Miquet JG, Bartke A, Turyn D \& Sotelo AI 2007 Differential regulation of membrane associated-growth hormone binding protein (MA-GHBP) and growth hormone receptor (GHR) expression by growth hormone $(\mathrm{GH})$ in mouse liver. Growth Hormone \& IGF Research 17 104-112. (doi:10.1016/j.ghir.2006.12.002)

Haiyan D, Wensheng L \& Haoran L 2010 Comparative analyses of sequence structure, evolution, and expression of four somatostatin receptors in orange-spotted grouper (Epinephelus coioides). Molecular and Cellular Endocrinology 323 125-136. (doi:10.1016/j.mce.2010.03.016)

Jiang H, Wang Y, Wu M, Gu Z, Frank SJ \& Torres-Diaz R 2007 Growth hormone stimulates hepatic expression of bovine growth hormone receptor messenger ribonucleic acid through signal transducer and activator of transcription 5 activation of a major growth hormone receptor gene promoter. Endocrinology 148 3307-3315. (doi:10.1210/ en.2006-1738) de Lecea L \& Bourgin P 2008 Neuropeptide interactions and REM sleep: a role for urotensin II? Peptides 29 845-851. (doi:10.1016/j.peptides. 2008.02.009)

Lehner U, Velic A, Schroter R, Schlatter E \& Sindic A 2007 Ligands and signaling of the G-protein-coupled receptor GPR14, expressed in human kidney cells. Cellular Physiology and Biochemistry 20 181-192. (doi:10.1159/000104165)

Le Mevel JC, Lancien F, Mimassi N, Leprince J, Conlon JM \& Vaudry H 2008 Central and peripheral cardiovascular, ventilatory, and motor effects of trout urotensin-II in the trout. Peptides 29 830-837. (doi:10.1016/j. peptides.2007.06.020)

Li Y, Liu X, Zhang Y, Zhu P \& Lin H 2007 Molecular cloning, characterization and distribution of two types of growth hormone receptor in orange-spotted grouper (Epinephelus coioides). General and Comparative Endocrinology 152 111-122. (doi:10.1016/j.ygcen.2007. 01.033)

Liu Q, Pong SS, Zeng Z, Zhang Q, Howard AD, Williams DL Jr, Davidoff M, Wang R, Austin CP, McDonald TP etal. 1999 Identification of urotensin II as the endogenous ligand for the orphan G-protein-coupled receptor GPR14. Biochemical and Biophysical Research Communications 266 174-178. (doi:10.1006/bbrc.1999.1796)

Lu W, Greenwood M, Dow L, Yuill J, Worthington J, Brierley MJ, McCrohan CR, Riccardi D \& Balment RJ 2006 Molecular characterization and expression of urotensin II and its receptor in the flounder (Platichthys flesus): a hormone system supporting body fluid homeostasis in euryhaline fish. Endocrinology 147 3692-3708. (doi:10.1210/en. 2005-1457)

Malagon MM, Molina M, Gahete MD, Duran-Prado M, Martinez-Fuentes AJ, Alcain FJ, Tonon MC, Leprince J, Vaudry H, Castano JP et al. 2008 Urotensin II and urotensin II-related peptide activate somatostatin receptor subtypes 2 and 5. Peptides 29 711-720. (doi:10.1016/j.peptides. 2007.12.015)

Marchese A, Heiber M, Nguyen T, Heng HH, Saldivia VR, Cheng R, Murphy PM, Tsui LC, Shi X, Gregor P et al. 1995 Cloning and chromosomal mapping of three novel genes, GPR9, GPR10, and GPR14, encoding receptors related to interleukin 8, neuropeptide Y, and somatostatin receptors. Genomics 29 335-344.

Matsushita M, Shichiri M, Fukai N, Ozawa N, Yoshimoto T, Takasu N \& Hirata Y 2003 Urotensin II is an autocrine/paracrine growth factor for the porcine renal epithelial cell line, LLCPK1. Endocrinology 144 1825-1831. (doi:10.1210/en.2003-0029)

Naor Z, Harris D \& Shacham S 1998 Mechanism of GnRH receptor signaling: combinatorial cross-talk of $\mathrm{Ca}^{2+}$ and protein kinase C. Frontiers in Neuroendocrinology 19 1-19. (doi:10.1006/frne.1997.0162)

Nobata S, Donald JA, Balment RJ \& Takei Y 2011 Potent cardiovascular effects of homologous urotensin II (UII)-related peptide and UII in unanesthetized eels after peripheral and central injections. American Journal of Physiology. Regulatory, Integrative and Comparative Physiology 300 R437-R446. (doi:10.1152/ajpregu.00629.2010)

Onan D, Hannan RD \& Thomas WG 2004 Urotensin II: the old kid in town. Trends in Endocrinology and Metabolism 15 175-182. (doi:10.1016/j.tem. 2004.03.007)

Pearson D, Shively JE, Clark BR, Geschwind II, Barkley M, Nishioka RS \& Bern HA 1980 Urotensin II: a somatostatin-like peptide in the caudal neurosecretory system of fishes. PNAS 77 5021-5024. (doi:10.1073/ pnas.77.8.5021)

Proulx CD, Simaan M, Escher E, Laporte SA, Guillemette G \& Leduc R 2005 Involvement of a cytoplasmic-tail serine cluster in urotensin II receptor internalization. Biochemical Journal 385 115-123. (doi:10.1042/ BJ20040807)

Proulx CD, Holleran BJ, Lavigne P, Escher E, Guillemette G \& Leduc R 2008 Biological properties and functional determinants of the urotensin II receptor. Peptides 29 691-699. (doi:10.1016/j.peptides.2007.10.027)

Qian Y, Yan A, Lin H \& Li W 2012 Molecular characterization of the GHRH/GHRH-R and its effect on GH synthesis and release in orangespotted grouper (Epinephelus coioides). Comparative Biochemistry and 
Physiology. Part B, Biochemistry \& Molecular Biology 163 229-237. (doi:10.1016/j.cbpb.2012.06.004)

Reindl KM \& Sheridan MA 2012 Peripheral regulation of the growth hormone-insulin-like growth factor system in fish and other vertebrates. Comparative Biochemistry and Physiology. Part A, Molecular \& Integrative Physiology 163 231-245. (doi:10.1016/j.cbpa.2012.08.003)

Rivas RJ, Nishioka RS \& Bern HA 1986 In vitro effects of somatostatin and urotensin II on prolactin and growth hormone secretion in tilapia, Oreochromis mossambicus. General and Comparative Endocrinology 63 245-251. (doi:10.1016/0016-6480(86)90162-0)

Saera-Vila A, Calduch-Giner JA \& Perez-Sanchez J 2007 Co-expression of IGFs and GH receptors (GHRs) in gilthead sea bream (Sparus aurata L.): sequence analysis of the GHR-flanking region. Journal of Endocrinology 194 361-372. (doi:10.1677/JOE-06-0229)

Seale AP, Yamaguchi Y, Johnstone WM III, Borski RJ, Lerner DT \& Grau EG 2013 Endocrine regulation of prolactin cell function and modulation of osmoreception in the Mozambique tilapia. General and Comparative Endocrinology 192 191-203. (doi:10.1016/j.ygcen.2013.05.011)

Sheridan MA \& Hagemeister AL 2010 Somatostatin and somatostatin receptors in fish growth. General and Comparative Endocrinology 167 360-365. (doi:10.1016/j.ygcen.2009.09.002)

Silvestre RA, Rodriguez-Gallardo J, Egido EM \& Marco J 2001 Inhibition of insulin release by urotensin II - a study on the perfused rat pancreas. Hormone and Metabolic Research 33 379-381. (doi:10.1055/s-2001-15414)

Singh R \& Rai U 2011 Immunomodulatory role of urotensins in teleost Channa punctatus. General and Comparative Endocrinology 170 613-621. (doi:10.1016/j.ygcen.2010.11.021)

Takahashi K, Totsune K, Murakami O, Arihara Z, Noshiro T, Hayashi Y \& Shibahara S 2003 Expression of urotensin II and its receptor in adrenal tumors and stimulation of proliferation of cultured tumor cells by urotensin II. Peptides 24 301-306. (doi:10.1016/S0196-9781(03) 00039-1)

Tostivint H, Joly L, Lihrmann I, Parmentier C, Lebon A, Morisson M, Calas A, Ekker M \& Vaudry H 2006 Comparative genomics provides evidence for close evolutionary relationships between the urotensin II and somatostatin gene families. PNAS 103 2237-2242. (doi:10.1073/ pnas.0510700103)
Tostivint H, Lihrmann I \& Vaudry H 2008 New insight into the molecular evolution of the somatostatin family. Molecular and Cellular Endocrinology 286 5-17. (doi:10.1016/j.mce.2008.02.029)

Vaudry H, Do Rego JC, Le Mevel JC, Chatenet D, Tostivint H, Fournier A, Tonon MC, Pelletier G, Conlon JM \& Leprince J 2010 Urotensin II, from fish to human. Annals of the New York Academy of Sciences 1200 53-66. (doi:10.1111/j.1749-6632.2010.05514.x)

Watson AM \& May CN 2004 Urotensin II, a novel peptide in central and peripheral cardiovascular control. Peptides 25 1759-1766. (doi:10.1016/ j.peptides.2004.04.016)

Wu YQ, Song Z, Zhou CH, Xing SH, Pei DS \& Zheng JN 2010 Expression of urotensin II and its receptor in human lung adenocarcinoma A549 cells and the effect of urotensin II on lung adenocarcinoma growth in vitro and in vivo. Oncology Reports 24 1179-1184. (doi:10.3892/ or_00000895)

Wu S, Li B, Lin H \& Li W 2012 Stimulatory effects of neuropeptide Y on the growth of orange-spotted grouper (Epinephelus coioides). General and Comparative Endocrinology 179 159-166. (doi:10.1016/j.ygcen. 2012.08.010)

Xing Y, Wensheng L \& Haoran L 2005 Polygenic expression of somatostatin in orange-spotted grouper (Epinephelus coioides): molecular cloning and distribution of the mRNAs encoding three somatostatin precursors. Molecular and Cellular Endocrinology 241 62-72. (doi:10.1016/j.mce.2005.05.008)

Xu S, Wen H \& Jiang H 2012 Urotensin II promotes the proliferation of endothelial progenitor cells through p38 and p44/42 MAPK activation. Molecular Medicine Reports 6 197-200. (doi:10.3892/mmr.2012.899)

Zeng ZP, Liu GQ, Li HZ, Fan XR, Liu DM, Tong AL, Zheng X \& Liu C 2006 The effects of urotensin-II on proliferation of pheochromocytoma cells and mRNA expression of urotensin-II and its receptor in pheochromocytoma tissues. Annals of the New York Academy of Sciences 1073 284-289. (doi:10.1196/annals.1353.032)

Zhang Y, Li Y, Wei R, Wang Z, Bu D, Zhao J, Pang Y \& Tang C 2008 Urotensin II is an autocrine/paracrine growth factor for aortic adventitia of rat. Regulatory Peptides 151 88-94. (doi:10.1016/j.regpep. 2008.10.004)

Received in final form 3 October 2013

Accepted 29 October 2013

Accepted Preprint published online 29 October 2013
(C) 2014 Society for Endocrinology Printed in Great Britain 